\title{
The State-Owned Company as a withholding agent of a flat-rate personal income tax - interpretation problems
}

\author{
Spółka Skarbu Państwa jako płatnik zryczałtowanego \\ podatku dochodowego od osób fizycznych - problemy \\ interpretacyjne
}

\begin{abstract}
This article aims at analysing Article 30(1) points 15) and 16) of the Personal Income Tax Act to indicate the conditions for recognizing a company, which is for the purposes of this article referred to as a State-Owned company, as a withholding agent of a flat-rate personal income tax. In the light of the aforementioned regulation, the withholding agent responsible for the settlement of personal income tax is a company in which the State Treasury and other public entities - indicated in this provision - hold directly or indirectly a majority of votes at a meeting of shareholders or general meeting of shareholders. The key element of this definition is the legislator's concept of "a majority of votes at a meeting of shareholders or general meeting of shareholders", which has become
\end{abstract}


the subject of a dispute between withholding agents and tax authorities as to whether the said majority of votes means "more than half of all votes", or "a simple majority". This study attempts to define the disputed issue by analyzing the position of the tax authorities expressed in individual interpretations of tax law provisions, the doctrine, and judicial as well as administrative decisions.

Keywords: withholding agent; flat-rate income tax; State-Owned company; a majority of votes at a shareholders' meeting.

Streszczenie. Przedmiotem opracowania jest analiza treści art. 30 ust. 1 pkt 15) i 16) ustawy o podatku dochodowym od osób fizycznych, wskazującego przesłanki do uznania spółki kapitałowej, nazwanej na potrzeby niniejszego artykułu spółką Skarbu Państwa, za płatnika zryczałtowanego podatku dochodowego od osób fizycznych. W świetle przywołanej regulacji płatnikiem odpowiedzialnym za rozliczenie podatku dochodowego od osób fizycznych jest ta spółka kapitałowa, w której Skarb Państwa i inne podmioty publiczne - wskazane w tym przepisie - dysponują bezpośrednio lub pośrednio większością głosów na zgromadzeniu wspólników albo na walnym zgromadzeniu. Kluczowym elementem tej definicji jest użyte przez ustawodawcę pojęcie „większości głosów na walnym zgromadzeniu wspólników albo walnym zgromadzeniu”, które stało się przedmiotem sporu toczącego się między płatnikami a organami podatkowymi co do tego, czy wspomniana większość głosów oznacza „więcej niż połowa wszystkich głosów”, czy „większość zwykła”. W niniejszym opracowaniu podjęto próbę zdefiniowania spornego zagadnienia, poddając analizie stanowisko organów podatkowych wyrażone w indywidualnych interpretacjach przepisów prawa podatkowego oraz dorobek doktryny i orzecznictwa sądowo-administracyjnego.

Słowa kluczowe: płatnik; zryczałtowany podatek; spółka Skarbu Państwa; większość głosów na zgromadzeniu.

\section{Introduction}

The issue of concern to this analysis was introduced to the Personal Income Tax $\mathrm{Act}^{1}$ by the amendment of 25 November $2015^{2}$. The amend-

1 Act of 26 July 1991 on Personal Income Tax (consolidated text: Dz.U. [Polish Journal of Laws] of 2019, poz. [item] 1387 with subsequent amendments). 
ment to the regulations was aimed at adding two categories of payments taxed at one of the highest rates in the Polish tax system, i.e. $70 \%$ to the catalogue of revenues subject to flat-rate income tax. The regulations in question are contained in Article 30(1) point 15) and 16) of the Personal Income Tax Act, which relate to compensation payments granted under non-competition laws as well as severance payments or compensation for shortening the notice period of an employment contract or a contract on the provision of management services, or its termination before the expiry of the period for which it was concluded. The entity which is subject to the withholding agent's obligations in this respect is a company in which the State Treasury, a local government unit, an association of local government units, a state legal person, or a municipal legal person holds directly or indirectly a majority of votes at a meeting of shareholders or at a general meeting of shareholders, including the votes held on the basis of agreements with other persons ${ }^{3}$. The legislator justified the said amendment by the need to limit the practice of granting exceptionally high severance payments and compensation, because of a non-competition clause, to members of the management boards of companies with the participation of the State Treasury ${ }^{4}$.

In the short period of the new regulations being in force, doubts arose on the taxpayers' side as to an understanding of the term of "holding a majority of votes at a shareholders' meeting"5 used therein. Individual interpretations of tax law provisions and decisions of administrative courts issued on this subject indicate the formation of two different positions in this respect as to the method of interpretation of the concept of "a majority of votes” used in Article 30(1) point 15) and 16) of the Personal Income Tax Act.

\footnotetext{
2 Act amending the Act on Personal Income Tax (Dz.U. of 2015, poz. 1992) hereinafter referred to as: "the amending act".

3 For editorial reasons, the term "public entities" was used to define the catalogue of entities referred to in the later part of the study.

4 Explanatory statement to the individual parliament member's bill to amend the Personal Income Tax Act, print No 22, (http://www.sejm.gov.pl).

5 Hereinafter referred to as “a majority of votes at a shareholders' meeting”.
} 
In the absence of a uniform position in this regard, an attempt was made by the author of this article to determine the meaning of the term “a majority of votes at a shareholders' meeting”. The basic research material consisted of individual interpretations of tax law and decisions issued in court and administrative proceedings regarding the issued individual interpretations. Therefore, considerations made against the background of positions of courts and tax authorities focus on an answer to the question whether the issue of "a majority of votes at a shareholders' meeting” should be interpreted in accordance with the view of administrative courts as "more than half" of the total number of votes entitled to be cast due to all rights established in a company, or in the light of the arguments of tax authorities as "more than others" in relation to the number of votes entitled to be cast at a shareholders' meeting.

\section{The position presented by tax authorities expressed in individual interpretations of tax law provisions}

Individual interpretations of tax law provisions regarding Article 30(1) point 15), and point 16) of the Personal Income Tax Act which are available on the website of the Ministry of Finance indicate an over 3-year long dispute between tax authorities and authors of requests for individual interpretations regarding an understanding of the phrase "a majority of votes at a shareholders' meeting.” In the light of the above-mentioned regulations holding a majority of votes at a shareholders' meeting of a company determines a recognition of that company as a withholding agent of a flatrate income tax.

The basis for the position of tax authorities in this regard is the assumption that the concept of a majority of votes is related to the number of votes that a shareholder (stockholder) disposes at a given meeting. In this sense, the concept of a majority of votes is taken as a variable state depending on the conditions of a given company, among others, on the degree of shareholding dispersion or attendance at meetings, which in 
effect leads to the thesis that the majority of votes at the meeting should be examined each time, separately for each subsequent shareholders' meeting. In the opinion of the authorities, the concept of a majority of votes means the actual exercise of power over the company, which should be considered in relation to the conditions of a given company, where the disposal of even a minority shareholding package can guarantee the permanent holding of the majority of votes at subsequent company meetings.

The authorities argue for the above mentioned thesis as follows:

firstly, by pointing out the similarity of the concept under examination to the identical phrase used for the purposes of determining the concept of a parent company, which is used by the Commercial Companies Code $^{6}$. According to the definition of a parent company contained in Article 4(1)(4)(a) of the Commercial Companies Code "a company is considered a parent company, among others, when it holds directly or indirectly a majority of votes at a shareholders' meeting or general shareholders' meeting, also as a pledgee or user, or in the management board of another company (subsidiary), also on the basis of agreements with other per-

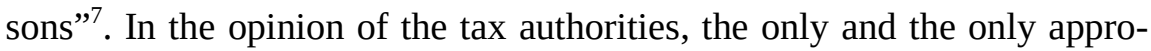
priate way to interpret the concept of a majority of votes at a shareholders' meeting is to assign it the meaning adopted for the purposes of the interpretation of the commercial law.

Secondly, they refer to the view presented in the literature on the term of holding a majority of votes. According to the tax authority's statement, Article 4(1)(4)(a) of the Commercial Companies Code does not

6 The Act of 15 September 2000 the Commercial Companies Code (consolidated text: Dz.U. [Polish Journal of Laws] of 2019, poz. [item] 505 with subsequent amendments).

7 The position included in the interpretations available in the Tax Information System Ministry of Finance search engine (http://sip.mf.gov.pl). Interpretations of the Head of the Uniform Tax and Customs Information Centre: of 13 April 2017 No 1462IPPB4.4511.61.2017.2.JM and No 1462-IPPB4.4511.59.2017.2.JM, of 18 April 2017 No 1462-IPPB1.4511.90. 2017.1.ES, of 10 May 2017 No 0114-KDIP33.4011.17.2017.1.AK, of 5 July 2017 No 0113-KDIPT2-3.4011.103.2017.1.AC. The same view was expressed by the Minister of Finance in an individual interpretation of 21 September 2016. No DD3.8222.2.99.2016.KDJ and the Head of the Tax Chamber in Warsaw in the interpretation of 7 November 2016 No 1462-IPPB4. 4511. 1094.2016.1.JK3. 
bind the dominance relationship to the shareholder's (stockholder's) share in the share capital of a given company, but to the number of votes at a shareholders' meeting (general shareholders' meeting) of another company. Based on the views presented in the literature, the Head of the Uniform Tax and Customs Information Centre pointed out that in determining the dominance relationship in question, it is decisive to establish an actual exercise of power over the company. Therefore, in such a case, the existence of dominance is possible, and thus holding the majority of votes by public entities also in the situation of owning a minority shareholding package $^{8}$.

Thirdly, they refer to the content of the explanatory statement drawn up for the purposes of the draft amending act ${ }^{9}$, in which the Ministry of Finance emphasised the role of the amendment in the pursuit of counteracting pathologies consisting of granting exceptionally high severance payments and compensation owing to the non-competition clause to members of management boards of companies with the participation of the State Treasury. In the context of this explanatory statement, the authorities argue that new regulations intended primarily to influence the formation of remuneration in companies with the participation of the State Treasury and to adjust their amount to reasonable and fair standards ${ }^{10}$. Therefore, the authority assumed that the legislator's intention was to cover by Article 30(1) point 15) and 16) of the Personal Income Tax Act all companies with the participation of the State Treasury and not only those in which it constitutes the majority.

Based on the above assumptions, tax authorities take the position that the withholding agent of the flat-rate income tax is a company in which

8 The position contained in the above-mentioned interpretations in which the tax authority refers to the view presented by M. Romanowski, The concept of a parent company in the Commercial Companies Code, „Państwo i Prawo” 2004, No 5, p. 80.

9 The explanatory statement to the Act was finally included in the content of the document published on the website of the President of the Republic of Poland as Information on the Act of 25 November 2015 amending the Personal Income Tax Act (http://www.prezydent.pl/prawo/ustawy/podpisane/art,4,listopad-2015-r.html).

10 Interpretation of the Head of the Tax Chamber in Warsaw of 7 November 2016 No 1462-IPPB4. 4511. 1094.2016.1.JK3, available in the Tax Information System Ministry of Finance search engine (http://sip.mf.gov.pl). 
public entities have a majority of votes understood as a majority in relation to the number of votes held by the other shareholders or stockholders at a given meeting of that company.

\section{Position contained in administrative court decisions}

The concept of “a majority of votes at a shareholders' meeting” was interpreted differently by administrative courts and by tax authorities in judgments issued in connection with the consideration of taxpayers' complaints regarding individual interpretations of the tax law. Although the starting point for the court's considerations was, as in the case of the position of tax authorities, the definition of a parent company contained in Article 4(1)(4)(a) of the Commercial Companies Code, the interpretation of this provision has led the courts to completely different conclusions. The court's position on the interpretation of the provision in Article 30(1) point 15) and 16) of the Personal Income Tax Act in its part related to the issue under consideration comes down to the statements discussed below.

The concept of a majority of votes at a shareholders' meeting, as a phrase clearly applicable to a commercial law, should be interpreted in a manner consistent with its meaning as defined on the basis of the Commercial Companies Code. In the light of the position of administrative courts, reference to the interpretation of the issue in question under the provisions of the Commercial Companies Code should be a starting point in the process of interpretation of the analysed issue. This interpretation, however, should not ignore the linguistic meaning of the formulation used in the provision of the Tax Act, as well as the context of its application and the basic goals that guided the legislator in drafting the amending act ${ }^{11}$.

In the context of the adopted interpretative assumptions, administrative courts indicated in their decisions that the phrase "a majority" should

11 See judgment of the Voivodeship Administrative Court in Warsaw of 12 March 2018, I SA/Wa 948/17, Central Database of Administrative Court Decisions (CBOSA). 
be understood as more than half in the colloquial and mathematical sense, i.e. $50 \%+1$. According to the courts, such an understanding results from the commonly accepted interpretation of the indicated regulation of the Tax Act, whereby public entities will have a majority of votes at a general shareholder's meeting, if these entities are entitled to the majority of votes calculated in relation to the total number of votes entitled to be a cast from all share rights, i.e. when they hold more than $50 \%$ of votes in relation to all votes attached to all share rights established by a given company ${ }^{12}$. The Voivodeship Administrative Court in Warsaw rightly noticed that the legislator introduced a condition to the discussed tax regulations that public entities should hold a majority of votes indicates that this is not a relative majority (i.e. more than others). As with such an interpretation, the sanctioning tax rate could already apply with a completely minimal, insignificant participation of the State Treasury in voting at a shareholders' meeting.

Used in the provisions of Article 30(1) point 15) and 16) of the Personal Income Tax Act, the term "a shareholders' meeting” should be interpreted in accordance with its basic meaning - as a company body, and not as a specific, each time convened assembly. In this regard, administrative courts do not share the position of tax authorities that the indicated provision of the Tax Act treats a meeting as a meeting of shareholders or stockholders in connection with the exercise of the resolution-passing function. On the contrary, according to the courts, the analysed issue is about these meetings in their basic, abstract meaning - as the bodies of companies. Therefore, the position of the courts indicates that the entity "holding directly or indirectly a majority of votes at a shareholders' meeting or general shareholders' meeting" will be only the entity that has the majority of votes calculated in relation to the total number of votes at-

12 These theses were formulated in the judgments of: Voivodeship Administrative Court in Warsaw of 12 March 2018, I SA/Wa 948/17, Voivodeship Administrative Court in Wrocław of 3 November 2017, I SA/Wr 827/17, Judgment of the Voivodeship Administrative Court in Gliwice of 23 January 2018, I SA / GI 978/17, CBOSA. 
tached to all rights, established on the basis of formalised criteria - documents constituting the company's system ${ }^{13}$.

\section{Comments on the background of positions of tax authorities and administrative courts}

Reading individual interpretations of tax law issued by tax authorities raises a number of doubts as to the correctness of these authorities' positions. Attention is drawn primarily to the laconic nature of the view, an omission of a linguistic interpretation in the process of interpretation of the examined provisions, as well as to an unjustified deduction of conclusions from the doctrine views cited in the explanatory statement. An excerpt from the publication by M. Romanowski's cited by the tax authorities on the importance of the dominance relationship (holding a majority of votes) intends only to cast doubt on the theses presented by companies that have applied for an interpretation of tax law provisions. Similar conclusions are derived from an interpretation of the concept of "a shareholders' meeting” in a sense of a specific meeting of shareholders or stockholders, which authorities also formulate on the basis of the cited publication of M. Romanowski. The lack of an in-depth analysis of the disputed concept for the purposes of individual interpretations, in particular narrowing an interpretation process to only one author's opinion, does not exhaust the research area and, therefore, is insufficient basis for accepting the position presented.

Turning to views contained in judgments of administrative courts, it should be emphasised that the judicature's interpretation of the concept of “a majority of votes at a shareholders' meeting” results from an in-depth analysis of the meaning of this term, which is based on directives of language interpretation and which is take into account the theses formulated by the doctrine of commercial law. It should be noted that the observa-

13 The position expressed in the cited judgments of the Voivodeship Administrative Court, and in addition, the judgment of the Voivodeship Administrative Court in Kielce of 26 October 2017, I SA/ Ke 535/17, CBOSA. 
tions of the courts both on the concept of "a majority of votes" and on the term of "a shareholders' meeting” are justified in the interpretation of these concepts made against the background of identical concepts used for the purposes of regulations of the Commercial Companies Code. Importantly, the courts' interpretation of provisions of the Personal Income Tax Act takes into account practical aspects of applying these regulations. In the opinion of the courts, adopting the understanding of a majority of votes as more than half allows it to clearly determine what percentage of votes in the overall settlement a given entity holds in each case in the ownership structure of the company. The conclusion of the Provincial Administrative Court in Gliwice ${ }^{14}$ that only such an understanding of this concept is verifiable appears to be reasonable. Referring to the interpretation made by tax authorities, this court pointed out that the interpretation of the authority is characterised by a high degree of ambiguity, leaving authorities with a large degree of an interpretation freedom, which under tax law provisions may lead to a violation of the constitutional principle of a specificity of tax law provisions.

\section{5. "A majority of votes at a shareholders' meeting" - a proposed meaning of the term}

An analysis of the positions of tax authorities and administrative courts allows to conclude that despite the significant differences in the manner in which the issue is interpreted in both cases considerations on the concept of "a majority of votes at a shareholders' meeting” refer to the provisions of the Commercial Companies Code regarding the concept of a parent company and to views related to this subject which are contained in the literature. It is difficult to disagree with this approach, given that the term - as argued by both authorities and courts - is appropriate for branches of

14 Judgment of the Voivodeship Administrative Court in Gliwice of 23 January 2018, I SA/GI 978/17, CBOSA. 
commercial law. It should be noted that the issue under examination has not yet been subject to publication in the field of tax law ${ }^{15}$.

The commercial law doctrine has developed two opposing concepts in this respect, both regarding the understanding of the term "a majority of votes", and the concept of “a shareholders' meeting”.

The first, advocated by the supporters of the M. Romanowski's views ${ }^{16}$ mentioned above and emphasised by tax authorities, indicates the possibility of a dominance relationship in case of owning even a minority shareholding package which guarantees, however, the permanent holding of an absolute majority of votes at subsequent shareholders' meetings of companies. In the light of this position, the sine qua non condition for a company to be considered a withholding agent within the meaning of the said regulation is the actual holding of a majority of votes by public entities at a specific, convened meeting of shareholders (stockholders). This means that the fulfillment of this condition will depend on conditions of a given company and on circumstances related to the course of a specific meeting of shareholders or stockholders, and, therefore, the fulfillment of this condition will be a variable circumstance.

The second view, approved by the jurisprudence, indicates that the understanding of the concept of a majority of votes should take into aacount disposing a majority of votes (more than 50\%) calculated in relation to the total number of votes attached to all share rights established by the company. In this case, the votes of a parent company - regardless of the voting method of other shareholders - constitute a majority, both absolute and relative. Consequently, in such a situation, the parent company gains a decisive influence both on the mere fact of adopting a resolution

15 A reference to the topic of the examined concept can be found in J. Marciniuk's publication Podatek dochodowy od osób fizycznych. Komentarz, (http://www.legalis.pl, 2017), in which the author commenting on the regulations of Article 30(1) points 15), and 16), defines the company making payments of severance and compensation listed in this provision - "a company with a majority shareholding of the State Treasury or local government units".

16 See S. Sołtysiński (ed.), Prawo spólek kapitałowych. System Prawa Prywatnego. Tom 17A (2015, pp. 799-801), and also S. Sołtysiński, A. Szajkowski, A. Szumański, J. Szwaja, A. Herbet, R. Gawałkiewicz, I.B. Mika, M. Tarska, Kodeks spółek handlowych. Komentarz do Art. 1-150 KSH (Tom I, 2012). 
by the meeting of shareholders or by the general meeting of the subsidiary, as well as on its content ${ }^{17}$. Representatives of the commercial law doctrine presenting such a manner of interpretation ${ }^{18}$ undermine M. Romanowski's view by arguing that this position is disputable. They also emphasise that the author himself recommends conducting such a qualification with great caution. In their opinion, the condition for the majority of votes referred to in Article 4(1)(4)(a) of the Commercial Companies Code should have "the value of a formalised criterion, referring to the share in the total number of votes, regardless of the practice and conditions of a given company (attendance at meetings or the degree of dispersion of shareholding, especially in public companies, etc.)".

The second of the presented concepts is justified by the purpose of the amendment to the Tax Act, which assumes striving to limit the practice of exceptionally high compensations and severance payments in companies with the participation of public entities. The justification for the "sanctioned" manner of taxing such payments was the legislator's reference to the need to counteract pathologies consisting in granting exceptionally high severance payments and compensation due to the noncompetition clauses to members of management boards of companies with the participation of the State Treasury. In the opinion of the drafters, the Act should affect a behaviour of the parties to such contracts and it should adjust the amount of severance payments and compensation to reasonable and fair standards. It is worth pointing out that the amendment in question is a part of a broadly defined process of legislative changes regarding the principles of determining the remuneration of persons performing managerial functions in decision-making and controlling bodies of companies with the participation of public entities, commonly known as "the Chim-

17 S. Włodyka, Prawo spółek kapitałowych, Prawo spółek handlowych. Tom 2, System prawa handlowego, Warszawa 2012, pp. 1539-1540; J. Bieniak, M. Bieniak, G. NitaJagielski, K. Oplustil, R. Pabis, A. Rachwał, M. Spyra, G. Suliński, M. Tofel, R. Zawłocki, Kodeks spółek handlowych. Komentarz, Legalis 2019; A. Opalski, Pojęcie spółki dominujq̨cej i zależne - zagadnienia wybrane, „Monitor Prawa Handlowego” (2012, No 3, p. 18).

18 Thesis supported by A. Opalski [in:] A. Opalski (ed.), Komentarz do art. 301-392. Kodeks spółek handlowych. Tom III A. Spółka akcyjna (2016, Legalis). 
ney Act”19. These provisions, effective from November 2016, specify, among others, forms and conditions for concluding contracts with persons managing companies with the participation of public entities, the so-called authorised entities ${ }^{20}$, including provisions regarding compliance with competition rules, as well as specifying the maximum limits on the amount of remuneration, severance payments, or compensation paid. This Act applies to all companies in which public entities have shares or stocks enabling them to exercise their rights regardless of a number of such rights. It is important, however, that the rights of these entities have the strength to fulfil the obligations set out in the Act. One of such obligations is taking actions aimed at shaping and applying in the company statutory principles of remuneration of members of its bodies, which consist, in particular, in leading to the vote by the company's general shareholders' meeting on draft resolutions on such remuneration and casting votes for their adoption.

The content of the above-mentioned regulations regarding the principles of determining remuneration in companies with the participation of public entities indicates that the addressee of these standards is the company in which public entities actually hold the decision-making power enabling them to introduce and apply these regulations in practice. Such decision-making power will certainly be provided to public entities with a majority of votes attached to all of the rights established in a given company. It seems that the legislator was also guided by this assumption, as indicated by the content of the discussion on the draft of the amending act conducted by members of the Public Finances Committee. ${ }^{21}$ The record of the session of this Committee proves that at the time of proceeding on the specific provisions of the draft of the amendment to the Act, the meeting

19 Act of 9 June 2016 on the principles of determining the remuneration of persons managing certain companies (consolidated text: Dz.U. of 2017, poz. 2190, with subsequent amendments), [,ustawa kominowa”].

20 The Act lists here the State Treasury, local government units or their associations, as well as state and municipal legal entities with share rights or rights under stocks in companies.

21 The full record of the meeting of the Public Finances Committee (No 2) of 25 November 2015 is available at http://www.sejm.gov.pl/. 
participants had no doubt that the discussed regulations referred to companies in which the State Treasury holds 50 plus $1 \%$ of shares (stocks).

In the process of interpreting provisions of the Tax Act one cannot ignore the language interpretation. It's priority in the process of applying the law has been repeatedly emphasised by the Constitutional Court in its decisions, in particular when the interpretation of tax provisions is aimed at determining the limits of taxation ${ }^{22}$. Dictionary definitions of the phrase “a majority” means "a larger proportion of a given group of things, phenomena or persons; the larger part of something in size", as well as "the greater part of some things or some group of people; more than half"23. Referring the above to the discussed regulation of the Personal Income Tax Act it should be assumed that this is not about the majority of votes held by one entity in relation to each of the other entities, because such a majority will not always provide the company with decision-making power at shareholders' meetings, referred to in the aforementioned "Chimney Act", and also invoked by tax authorities in the justification of the interpretations issued. Referring to a specific example in which the voting rights of three shareholders in a company are respectively: $40 \%$, $30 \%$, and $30 \%$ of votes, two conclusions can be drawn:

1. A shareholder who holds $40 \%$ in the total number of votes has more votes in relation to each of the other shareholders.

2. The majority referred to above, however, does not provide grounds for considering that the shareholder has a majority of votes in the total number of all votes, which is equivalent to stating that it holds no decision-making power at shareholders' meetings.

The aforementioned majority which gives decision-making power at shareholders' meetings, can occur only in strictly defined cases, if additional circumstances conditioning the course of a given meeting allow it. The notion of a majority of votes understood in this manner, if accepted on the basis of the definition of a parent company within the meaning of the provisions of commercial law, appears unacceptable for the purposes

\footnotetext{
Cf. R. Mastalski, Prawo podatkowe, Warszawa 2018, pp. 150-151.

23 Dictionary of the Polish language PWN (https://sjp.pwn.pl/sjp), and Wiktionary (https://pl.wiktionary.org/wiki).
} 
of interpreting provisions of the Tax Act which indicate that the determination of the subject of taxation cannot make variable and uncertain factors as a reference point. Making statutory obligations of the withholding agent dependent on the circumstances related to the course of a specific meeting of shareholders of a company would leave a large margin of uncertainty as to how to define the withholding agent or the purposes of the discussed regulations. This is because in the light of the thesis formulated in this manner, a given company may be identified as a withholding agent or not, depending on the will manifested by its shareholders, which is given a concrete expression during voting at a specific shareholders' meeting. In addition, the indicated interpretation of the concept under examination would imply further doubts concerning an interpretation related to the choice of the general shareholders' meeting which should be referred to in a particular situation. In practice, this solution would lead to an illogical situation in which in the absence at a given meeting of all shareholders other than public entities, the majority of votes could be held even by a public entity with one share (one holding of stock). This method of interpretation cannot be accepted in the context of the analysed provisions of the Personal Income Tax Act, because it would violate the principle of a specificity and certainty of law.

In the view of the above, it should be stated that only if public entities hold the majority of at least $50 \%+1$ vote in the total number of votes it can be clearly and without doubt determined which company meets the conditions for recognition as a withholding agent within the meaning of Article 30(1) point 15) and 16) of the Personal Income Tax Act. One should agree with the statement of the Voivodeship Administrative Court in Gliwice in the above-cited judgment that: "Only such an understanding of this concept is verifiable”, because it gives the possibility of real and precise determination of the majority position of public entities in a given company.

It is also worth indicating that the adoption of this conception is additionally justified in the aspect of legal conditions of listed public limited companies (so-called public companies). In case of such companies, in accordance with the applicable provisions, shareholders holding a package of shares amounting to at least $5 \%$ of the total share capital are subject to 
disclosure $^{24}$. Depriving these companies of a knowledge about its entire shareholding structure makes it impossible to determine the majority of votes held by public entities in a manner indicated by tax authorities. Omitting this aspect for the purposes of interpreting the examined issue would lead to a removal from the regulation of the analysed provision of the Personal Income Tax Act of all public companies, which certainly was not the intention of the legislator. An issue of the package of rights not disclosed in public companies will be valid regardless of the adopted method of determining the majority of votes; however, only the interpretation of the concept of "a majority" indicating its understanding as "more than half" in relation to all capital rights in a company will allow for unambiguous and precise determination of dominance of public entities at a shareholders' meeting of a public company.

\section{Conclusions}

It is difficult to disagree with the views of administrative courts that the expression "a majority of votes at a shareholders' meeting” used for the purposes of Article 30(1) point 15) and 16) of the Personal Income Tax Act is a clearly evident concept of commercial law regulations. It should be noted, however, that the application of definitions in tax acts which are appropriate to provisions outside the tax system does not always prove to be a desired solution. Hence, the courts rightly pointed to the need to refer to the linguistic meaning of the term "a majority", and to take into account the context of its use in the Tax Act. Therefore, referring to the position of jurisprudence, it should be stated that only the understanding of "a majority of votes" as "more than half" of votes at a shareholders' meeting of a company understood as its body makes it possible to clearly determine what percentage of votes in the general account is held by public entities at a meeting of shareholders (stockholders) of a company. However, for a proper reading of the legal norm contained in Article 30(1) point 15) and

24 Article 69(1) of the Act of 29 July 2005 on Public Offering and Conditions for the Introduction of Financial Instruments to the Organised Trading System and on Public Companies (consolidated text: Dz.U. of 2019, poz. 623). 
16) of the Personal Income Tax Act, it should be assumed that this refers to a majority of votes at a meeting understood as the body of a company, defined in accordance with the regulations of the Commercial Companies Code, because the adoption of the meaning of this term in the manner indicated by tax authorities would distort the purpose of the cited tax law provision and would make it impossible to apply this regulation in practice.

In view of the proposed definition of "a majority of votes at a shareholders' meeting” the withholding agent of a flat-rate personal income tax within the meaning of the analysed regulations of the Personal Income Tax Act will be a company in (stock or share) capital of which public entities hold more than $50 \%$ of votes.

\section{Bibliography:}

Bieniak J., Bieniak M., Nita-Jagielski G., Oplustil K., Pabis R., Rachwał A., Spyra M., Suliński G., Tofel M., Zawłocki R., Kodeks spółek handlowych. Komentarz, C.H. Beck, Warszawa 2019.

Marciniuk J., Podatek dochodowy od osób fizycznych. Komentarz, Legalis 2017.

Mastalski R., Prawo podatkowe, C.H. Beck, Warszawa 2018.

Opalski A. (ed.) Komentarz do Art. 301-392, Kodeks spółek handlowych. Volume III A. Spółka akcyjna. Legalis 2016.

Opalski A., Pojęcie spółki dominujq̨cej i zależnej w KSH - zagadnienia wybrane „Monitor Prawa Handlowego” 2012, No 3, pp. 17-25.

Romanowski M., Pojęcie spółki dominującej w kodeksie spółek handlowych „Państwo i Prawo” 2004, No 5, pp. 76-87.

Sołtysiński S. (ed.), Prawo spółek kapitałowych. System Prawa Prywatnego. Tom 17A, C.H. Beck, Instytut Nauk Prawnych PAN, Warszawa 2015.

Sołtysiński S., A. Szajkowski, A. Szumański, J. Szwaja, A. Herbet, R. Gawałkiewicz, I.B. Mika, M. Tarska, Kodeks spółek handlowych. Komentarz do art. 1-150 KSH. Tom I, C.H. Beck, Warszawa 2012.

Włodyka S., Prawo spółek handlowych. Tom 2. System Prawa Handlowego, C.H. Beck, Warszawa 2012. 